\title{
Protein reduction of natural rubber films through leaching solvent
}

\author{
Lih Jiun $\mathrm{Yu}^{1, *}$, Christopher Wong Yoke $\mathrm{Chi}^{1}$, Vishantini Tangavaloo ${ }^{2}$, Keuw Wei $\mathrm{Lim}^{3}$, and Mou'ad A Tarawneh \\ ${ }^{1}$ Department of Mechanical Engineering, Faculty of Engineering, Technology \& Built Environment, UCSI University, No \\ 1, Jalan Menara Gading, UCSI Heights, 56000, Kuala Lumpur, Malaysia. \\ ${ }^{2}$ Top Glove (F12), Lot 4960, Jalan Teratai, 6th Miles, Off Jalan D.E, Meru, 41050 Klang, Selangor, Malaysia. \\ ${ }^{3}$ Top Glove (25) PT 64593, Jalan Dahlia/KU8, Kawasan Perindustrian Meru, Timur, 41050 Klang, Selangor, Malaysia. \\ ${ }^{4}$ Department of Physics, College of Science, Al-Hussein Bin Talal University, Ma'an, P.O Box 20, Jordan.
}

\begin{abstract}
The finished product natural rubber latex gloves consist of latex proteins, which may pose a risk of allergic reactions in some latex-sensitive individuals. The allergic reactions depend on mild exposure to heavy exposure. An alternative solution to allergic users, usage of latex-free gloves are lack of elasticity and less comfort. This study aims to investigate natural rubber films protein reduction via three types of leaching solvent: acetic acid, sodium hydroxide, and ethanol in the leaching process. Then the influence of leaching solvent concentration on the physical properties of natural rubber gloves was analyzed. It was found that the acetic acid performed greater protein reduction effect $(30.07 \%)$, followed by sodium hydroxide $(27.77 \%)$, whereas the ethanol was shown to be less significant to protein reduction. All samples were fulfilling the mechanical properties as required in ASTM standard.
\end{abstract}

\section{Introduction}

Natural rubber is obtained from the Hevea brasiliensis tree, a family tree called Euphorbiacieae and generally also known as the rubber tree. Natural rubber latex contains more than 250 polypeptides and at least 60 of which are an indication of immunoglobulin $\mathrm{E}$ ( $\mathrm{IgE}$ ) binding properties [1]. The natural rubber is obtained through a rubber tapping process, where it is then collected from the incision made on the bark of the tree and is derived of $34 \%$ rubber cis $-1,4$ - polyisoprene, 2 $-3 \%$ proteins, $0.1-0.5 \%$ sterol glycosides, $1.5-3.5 \%$ resins, $0.5-1.0 \%$ ash, $1.0-2.0 \%$ sugars, and $55-65$ $\%$ water [2]. The unprocessed latex is contained in an ammonia solution to avoid microorganism growth. It includes the allergens (cellular proteins, amino acids, and lipids) that activate sensitization [3]. Latex allergies are most customarily known with people who have frequent exposure to latex. The severity of the allergic reactions to latex can be from mild to intense.

People with allergic reactions to natural rubber latex should be able to work in the healthcare or manufacturing industry with careful procedures. A safe alternative is the reduction of exposure to latex without the individual from leaving the place of employment. Alternative gloves made of non-natural rubber materials are lacking elasticity and less comfort to be worn by the users.

In conjunction with the allergy issues, the rubber glove manufacturing has improved also developed the glove quality and lower the sensitization of the glove. The developments will be responsible for a powerful barrier and minimize the risk of developing latex allergy. The switching to low-powdered natural rubber latex gloves produces results in a decrease in the incidence [4] After few years of establishment of low-allergen or nonpowdered gloves in the work environment. With the installation of the new institution, the prevalence of healthcare workers having the latex allergic reactions decreases by half. Besides that, the enhancements include the use of low-protein structure, multiple leaching (washing with chemicals) protocols, double centrifuge regime or deproteinization via enzyme [5]. The tackiness of glove is reduced by the chlorination process [6].

The protein reduction methods employed above involved high investment cost or high waste treatment cost. There is a need to develop an effective protein reduction method to meet consumer's expectation in economic approach yet less harmful towards the environment. Baur et al. [7] displayed that the potassium hydroxide solution was more effective in leaching protein content than water. In this paper, the influence of different leaching solvent on protein reduction and their corresponding mechanical properties were studied.

\section{Materials and methods}

\subsection{Materials and reagents}

For the selection of leaching solvents, the solvents chosen were based on three different chemical compounds, which were acid, alkaline, and alcohol. The solvents were selected based on economic aspect and their temperature tolerance which matches the gloves

* Corresponding author: y jiun@ @otmail.com 
manufacturing operating condition. Different concentration of solvent was used as $0.4 \mathrm{M}, 0.6 \mathrm{M}, 0.8 \mathrm{M}$, whereas $0 \mathrm{M}$ (water) as a control set. The prepared solvent was preheated to $70^{\circ} \mathrm{C}$ before immersing the semi-finished gloves product. This is to reduce the protein contents but not destroy the rubber. Table 1 shows the properties of selected leaching solvent.

Table 1. Leaching solvents used in the experiment

\begin{tabular}{ccccc}
\hline Solvent & Type & $\begin{array}{c}\text { Molecular } \\
\text { Weight } \\
(\mathrm{g} / \mathrm{mol})\end{array}$ & $\mathrm{pH}$ & $\begin{array}{c}\text { Boiling } \\
\text { Point } \\
\left({ }^{\circ} \mathrm{C}\right)\end{array}$ \\
\hline $\begin{array}{c}\text { Acetic Acid } \\
\mathrm{CH}_{3} \mathrm{COOH} \\
\text { Sodium } \\
\begin{array}{c}\text { Hydroxide } \\
\mathrm{NaOH}\end{array}\end{array}$ & Acid & 60.05 & 1 & 117.9 \\
$\begin{array}{c}\mathrm{Ethanol} \\
\mathrm{C}_{2} \mathrm{H} \mathrm{OH}\end{array}$ & Alkaline & 39.99 & 14 & 1388 \\
\hline
\end{tabular}

\subsection{Experimental set-up}

The experiment set-up presented in Fig. 1. Vulcanized latex films were dipped in the prepared leaching solvent for $30 \mathrm{~s}$ then rinse with water for 1 minute to remove residual before completely dry in the oven. The dried gloves sample were collected for protein content test and mechanical properties test.

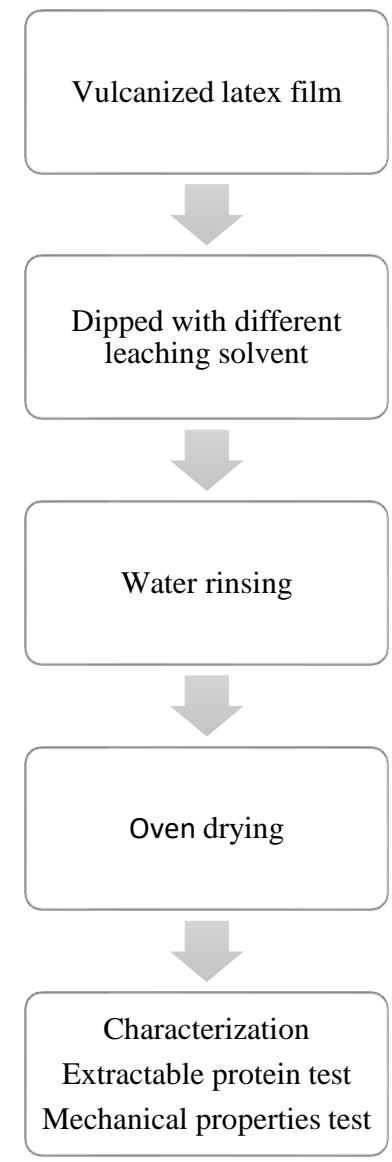

Fig. 1. Experiment set-up.

\subsection{Characterization and testing}

In protein content test, the standard of ASTM D 5712 has been used in determining the amount of total aqueous extractable protein associated with natural rubber, latex, and elastomeric products. The testing procedure was done according to ASTM D 5712 including extraction of water-soluble protein in phosphate-buffered saline (PBS), centrifuge to concentrate and separate watersoluble protein, then quantified by Lowry method in a unit of $\mathrm{ug} / \mathrm{dm}^{2}$. Protein content $<200 \mathrm{ug} / \mathrm{dm}^{2}$ are acceptable.

For mechanical properties test, ASTM D3578 has been used in this tensile test; this standard is to test tensile strength and elongation in natural rubber latex films of both fresh and aged samples. The accelerated aging process takes in $70^{\circ} \mathrm{C}$ oven condition for seven days.

\section{Results and discussion}

\subsection{Results for control set}

The results of the control set (dipping with water) were tabulated in Table 2. These results will be used as a reference sample for comparison with the samples with solvent treatment.

Table 2. Results of control set $(0 \mathrm{M})$

\begin{tabular}{cc} 
Table 2. Results of control set $(0 \mathrm{M})$ & \\
\hline Parameter & Value \\
\hline $\mathrm{pH}$ & 7.0 \\
Extractable protein content $\left(\mu \mathrm{g} / \mathrm{dm}^{2}\right)$ & 137.17 \\
Tensile strength of fresh samples $(\mathrm{MPa})$ & 24.22 \\
Elongation of fresh samples $(\%)$ & 822.69 \\
Tensile strength of aged samples (MPa) & 20.86 \\
Elongation of aged samples (\%) & 784.92 \\
\hline
\end{tabular}

The results in Table 2 shows both tensile and elongation values of control samples are deteriorated after aging. All the properties in Table 2 (both the extractable protein content as well as mechanical properties) are fulfilling ASTM standard properties requirements.

\section{2 $\mathrm{pH}$ of solvents}

The $\mathrm{pH}$ values of solvent at different concentration are listed in Table 3

Table 3. $\mathrm{pH}$ of solvents in different concentration

\begin{tabular}{cccc}
\hline Concentration & \multicolumn{3}{c}{$\mathrm{pH}$} \\
\cline { 2 - 4 } & Acid & alkaline & alcohol \\
\cline { 2 - 4 } $0.4 \mathrm{M}$ & 4.3 & 11.6 & 7.3 \\
$0.6 \mathrm{M}$ & 4.1 & 12.1 & 7.4 \\
$0.8 \mathrm{M}$ & 3.8 & 12.5 & 7.6 \\
\hline
\end{tabular}

From Table 2, the control set's $\mathrm{pH}$ was neutral at 7.0. It can be seen that addition acid concentration is driven the $\mathrm{pH}$ towards lower value and additional of alkaline is increasing the $\mathrm{pH}$ values (Table 3). It can be seen that 
the addition of alcohol concentration became slight basic due to the presence of hydroxyl group in ethanol.

\subsection{Extractable protein content in different leaching solvent}

The extractable protein content of latex samples leached in a different solvent is shown in Fig. 2. It was observed that there is no significant reduction of extractable protein content by alcohol leaching solvent. The ethanol was easily vaporized although boiling point of ethanol was higher at $1 \mathrm{~atm}$ pressure. In another hand, the acetic acid and sodium hydroxide were easily reacted with water and leached the protein. Both (acetic Acid and sodium hydroxide) have shown great protein reduction and the results close to call in Fig. 2.

The reduction of extractable protein content is due to hydrolysis of the high molecular weight protein by alkaline solution [8,9]. During hydrolysis, the high molecular weight of proteins is broke down into small pieces of peptides as well as amino acids, which are then easily removed from the latex film by washing. The results are in agreement with [9] where stating that the protein reduction is effective at high $\mathrm{pH}$ values when alkaline leaching solvent is used. It was reported that the addition of acid in latex compounds able to reduce the extractable protein content of produced samples during the compounding process. Nevertheless, aggregation of latex lumps and denaturized of protein occurs when $\mathrm{pH}$ level is low $(\mathrm{pH}<2)$, due to the low solubility of the protein in polar solvents [10]. The usage of acid as leaching solvent in this work was found to be effective as an alkaline solvent. Both alkaline and acid leaching solvent has the highest protein reduction at a concentration of $0.6 \mathrm{M}$, achieving $30.07 \%$ and $27.77 \%$ protein reduction as compared to control samples.

The interaction of leaching protein with alkaline and acid solvent are based on the presence of hydroxide ion and hydrogen ion with the latex film's surface. The hydrogen ion from the acetic acid counteracts the negatively charged protein layer in the leaching process. The external rubber particles were denatured by acetic acid, and the protein content was reduced. Such as for sodium hydroxide, the hydroxide ion from the sodium hydroxide neutralizes the negatively charged protein layer, contributed to the lowering of latex film's surface protein content. At high leaching solvent concentration $(0.8 \mathrm{M})$, the extractable protein level dipped with acid and alkaline leaching solvent are increased to 101 $\mathrm{ug} / \mathrm{dm}^{2}$. The high protein level is possibly due to insufficient rinsing to remove the surface residue protein and leaching solvent that remained on latex film when leaching solvent concentration is high.

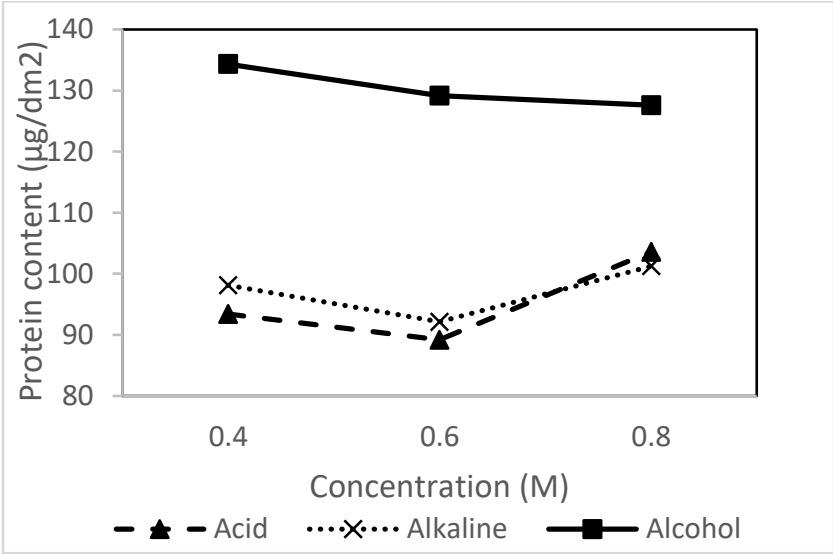

Fig. 2. The extractable protein level of gloves leached with a different solvent.

\subsection{Tensile strength}

Fig. 3 and Fig. 4 show the tensile strength of fresh samples and aged sample after leaching with different solvents. From Fig. 3, it can be seen that there are no noteworthy changes in tensile strength, regardless of the type of solvent use. The maximum changes of tensile strength percent deviate from control set value (24.22 $\mathrm{MPa}$ ) is up to $7.31 \%$. The increment of solvent's concentration has no impact on the tensile strength, except alcohol. It can be observed that the tensile strength of the supposed solvent is in reducing trend as the alcohol content increased. Protein denaturation by alcohol has organized the hydrophobic interior of the proteins [11,12], led to a weakening of the hydrocarbon chain and decreased in mechanical properties of the samples.

In Fig. 4, the effect of leaching solvent of aged samples can be neglected. The tensile strength of all samples was degraded after aged, range from $17.90 \mathrm{MPa}$ to $23.03 \mathrm{MPa}$ in Fig. 4. The degradation of tensile strength is attributed to the curing process of aged latex film.

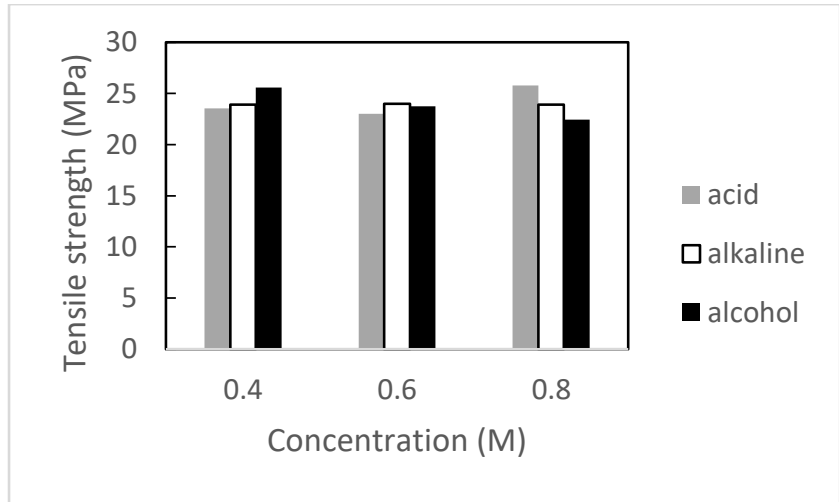

Fig. 3. Tensile strength of samples leached with different solvents (fresh). 


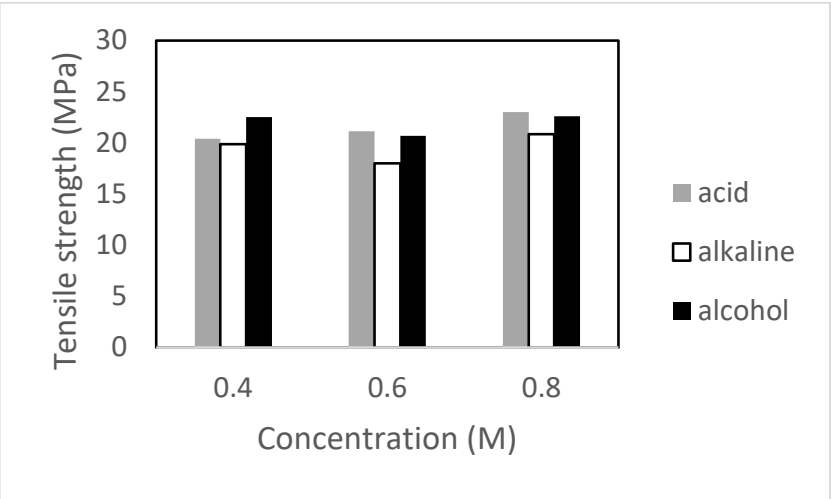

Fig. 4. Tensile strength of samples leached with different solvents (aged)

\subsection{Elongation}

Fig. 5 displays elongation of samples after leached with a different solvent. In Fig. 5, the elongation values of all samples (in the range of $770.46 \mathrm{MPa}$ to 898.00 $\mathrm{MPa}$ ) are approximate to the control value at 784.92 $\mathrm{MPa}$. Generally, the basics solvent has no impact on elogation of the latex films. It was obvious that all samples dipped with acid solvent exhibits greater elongation values than other samples. The denaturation process of vulcanized latex films by acidic leaching and thermal probably causing aggregation of protein molecules disentangles with the latex particles, hence decrease the reinforcement effect of latex structure and improve the elongation properties. The results (adding acid in leaching process) are desirable, as compared to the approach of adding acid during latex compounding process. The presence of acid in prevulcanizelatex compounds resulting a degradation in elongation [13].

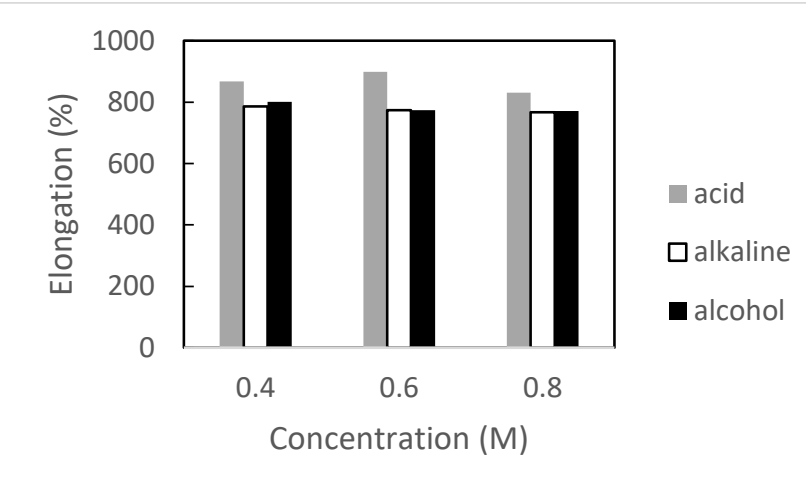

Fig. 5. Elongation of samples leached with different solvents (fresh)

Fig. 6 shows elongation of leached samples after aged for seven days. Refer to Figure 6, all elongation values of aged samples (763.14 $\mathrm{MPa}$ to $964.66 \mathrm{MPa}$ ) are proximate to the control value $(822.69 \mathrm{MPa})$. This indicates that usage of various solvent from $0.4 \mathrm{M}-0.8 \mathrm{M}$ concentration has less impact toward elongation properties of aged latex films. Mainly, all the elongation of aged samples demonstrating a slight decrease trend as the concentration of leaching solvent improved, attribute to the hydrolysis of protein in polar solvents. It was consistent that all samples dipped in acid exhibits higher elongation than other solvents, be it the fresh samples (Fig. 5) or else aged samples (Fig. 6).

\section{Conclusion}

General, all the samples passed the requirement of ASTM protein test and mechanical properties. In cooperation acid and alkaline leaching solvent presented protein reduction of minimum $33 \mu \mathrm{g} / \mathrm{cm}^{2}$. Highest protein reduction is achieved at $0.6 \mathrm{M}$ of acid solvent $(30.07 \%)$. On the contrary, alcohol has least impact on protein reduction. All solvents were found to have less impact of tensile as well as elongation of the latex films, proposed that the use of a solvent is only impacted on the surface protein reduction.

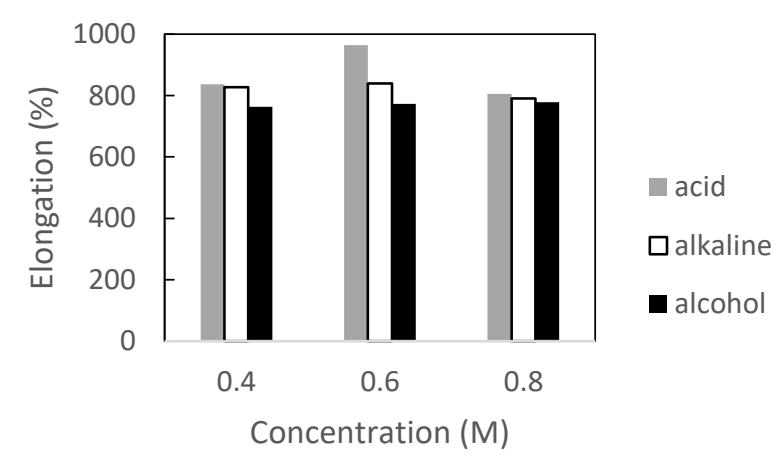

Fig. 6. Elongation after samples leached with different solvents (aged)

This research was technically supported by Top Glove Sdn Bhd. The research results are not reflecting the actual results from the manufacturing process and not obtained from Top Glove laboratory prototype.

\section{References}

[1] Hamilton, R. G., Diagnosis of natural rubber latex, Allergy, 2002, 21-22.

[2] Cacioli, P., Introduction to latex and the rubber industry, 1997, 1173-1175.

[3] Yip, E. and Cacioli P., The manufacture of gloves from natural rubber latex, 2002, 110 (2), 3-16.

[4] Bousquet, J., Flahault, A., Vandenplas, O., Ameille, J., Durron J.J, Pecquet, C., Chevrie, K., Annesi-Maesano, I., Natural rubber latex allergy among health care workers: a systematic review of evidence, Journal of Allergy Clinical Immunology, 2006, 118(2), 447-454.

[5] Perrella, F.W \& Gaspari, A.A. Natural rubber latex protein reduction with an emphasis on enzyme treatment. Methods, 2002, 27, 77-86. 
[6] Truscott, W. Glove powder reduction and alternative approaches. Methods, 2002, 27, 69-76.

[7] Baur, X., Rennert J, and Chen Z. Latex allergen elimination in natural latex sap and latex gloves by treatment with alkaline potassium hydroxide solution. Allergy, 1997, 52(3), 306-11.

[8] Archer, B.L. Barnard, D., Cockbain, E.G., Dickenson, P.B., McMullen, A.I. Structure Composition of the biochemistry of Hevea Latex, in Bateman, L (Ed), The Chemistry and Physics of Rubber-like Substances, McLaren, London, 1963, 41-72.

[9] Maznah, K.S., Bahrin, A., Hanafi, I., Azhar, M.E., Mas Rosemal Hakim, M.H., Effect of soaking in potassium hydroxide solution of the curing, tensile properties and extractable protein content of natural rubber latex films. Polymer Testing, 2008, 27, 1013-1016.

[10] Nick Pace, C., Trevino, S., Prabhakaran, E. \& Martin Scholtz, J. Protein structure, stability and solubility in water and other solvents, Phil. Trans. R. Soc. Lond. B. 359, 1225-1235.

[11] Herskovits, T.T., Gadegbeku, B., Jaillet, H. 1970. On the structural stability and solvent denaturation of protein I. Denaturation by the alcohol and glycols. Journal of Biological Chemistry. 245, 2588-2598.

[12] Morr, C.V. \& Lin, S.H.C. Preparation and properties of an alcohol-precipitated whey protein concentrate. Journal of Dairy Science. 53 (9), 1162-1170.

[13] Maznah, K.S., Baharin, A., Hanafi, I., Azhar, M.E., Mas Rosmal Hakim, M.H., Effect of acid treatment on extractable protein content, crosslink density and tensile properties of natural rubber latex films., Polymer Testing, 2008, 27, 823-826. 